\title{
Micralestes (Characiformes, Alestidae) of the lower Congo River, with a description of a new species endemic to the lower Congo River rapids in the Democratic Republic of Congo
}

\author{
MELANIE L.J. STIASSNY ${ }^{1} \&$ VICTOR MAMONEKENE ${ }^{2}$ \\ ${ }^{1}$ American Museum of Natural History, Department of Ichthyology, Central Park West at 79 ${ }^{\text {th }}$ Street, New York, NY 10024, USA. \\ E-mail: mljs@amnh.org \\ ${ }^{2}$ Institut de Développement Rural, Université Marien Ngouabi, B.P. 69 Brazzaville, Republic of Congo. \\ E-mail: mamonekene@hotmail.com
}

\begin{abstract}
A new dwarf alestid from the vicinity of Inga on the lower Congo River, Bas Congo Province, Democratic Republic of Congo is described. Assignment of the new taxon to the poorly defined genus, Micralestes, is discussed and justified on the basis of available morphological character data. With the recognition of Micralestes schelly sp. nov., a total of six Micralestes are now known to inhabit the $350 \mathrm{~km}$ stretch of the Congo River from Pool Malebo to Boma near the river's estuary. These are Micralestes acutidens (Peters, 1852), Micralestes humilis Boulenger, 1899, Micralestes lualabae Poll, 1967, Micralestes holargyreus (Günther, 1873), Micralestes stormsi Boulenger, 1902, and the new species Micralestes schelly. Of these Micralestes schelly and Micralestes holargyreus are considered herein as restricted-range endemics of the lower Congo River. An illustrated key to Micralestes of the lower Congo River is provided.
\end{abstract}

Key words: Micralestes, lower Congo River, identification key, new species

\section{Résumé}

Un nouveau Alestidae nain est décrit des environs d'Inga dans le cours inférieur du fleuve Congo, Province du BasCongo en République Démocratique du Congo. L'assignation du nouveau taxon au genre Micralestes mal défini, est discutée et justifiée sur la base des données des caractères morphologiques disponibles. Avec la reconnaissance de Micralestes schellyi sp. nov., le nombre total de Micralestes vivant sur les $350 \mathrm{~km}$ de rapides du Bas-Congo, allant du Pool Malebo à Boma vers l'estuaire est maintenant de six. Il s'agit de Micralestes acutidens (Peters, 1852), Micralestes humilis Boulenger, 1899, Micralestes lualabae Poll, 1967, Micralestes holargyreus (Günther, 1873), Micralestes stormsi Boulenger, 1902 et Micralestes schelly décrit dans ce travail. De ses espèces, Micralestes schelly et Micralestes holargyreus sont dans la gamme restreinte des endémiques du cours inférieur du fleuve Congo. Une clé illustrée des Micralestes de cette région est donnée.

\section{Introduction}

Generic-level classification of the African Alestidae, and more particularly that of the taxa assigned to the Petersiini, or 'dwarf African alestids', is generally poorly supported by apomorphy-based diagnoses (Stiassny and Schaefer, 2005; Zanata and Vari, 2005; Paugy and Schaefer, in press). Despite these shortcomings, an accurate accounting of species diversity remains of central importance for the phylogenetic resolution of this group as well as for realistic conservation efforts in the region. Species discovery and description remain the 
fundamental task for advancing biodiversity studies in poorly documented regions such as the Congo River basin. Fortunately the recent phylogenetic analysis of Zanata and Vari (2005) provides a provisional character-based scheme of alestid intrarelationships that can serve as an aid to generic assignment for species of this taxonomically problematical assemblage of African fishes. Based primarily on the character scheme of Zanata and Vari (2005) a newly discovered alestid from the vicinity of Inga on the lower Congo River is herein assigned to the poorly defined genus Micralestes and a phylogenetic rationale for this generic assignment is presented.

Roberts \& Stewart (1976) in their work on the fishes of the lower Congo River reported the presence of two Micralestes in their collections: M. acutidens (Fig. 1A) and M. humilis (Fig. 1C). Recent collections in the region also include specimens of M. lualabae (Fig. 1D), M. stormsi (Fig. 1E) and M. holargyreus (Fig. 1B). In addition to these, a collection made in the vicinity of Inga revealed the presence of a population of diminutive alestid that appears most closely to resemble Micralestes but that are not assignable to any described Micralestes or to any other species dwarf African alestid.

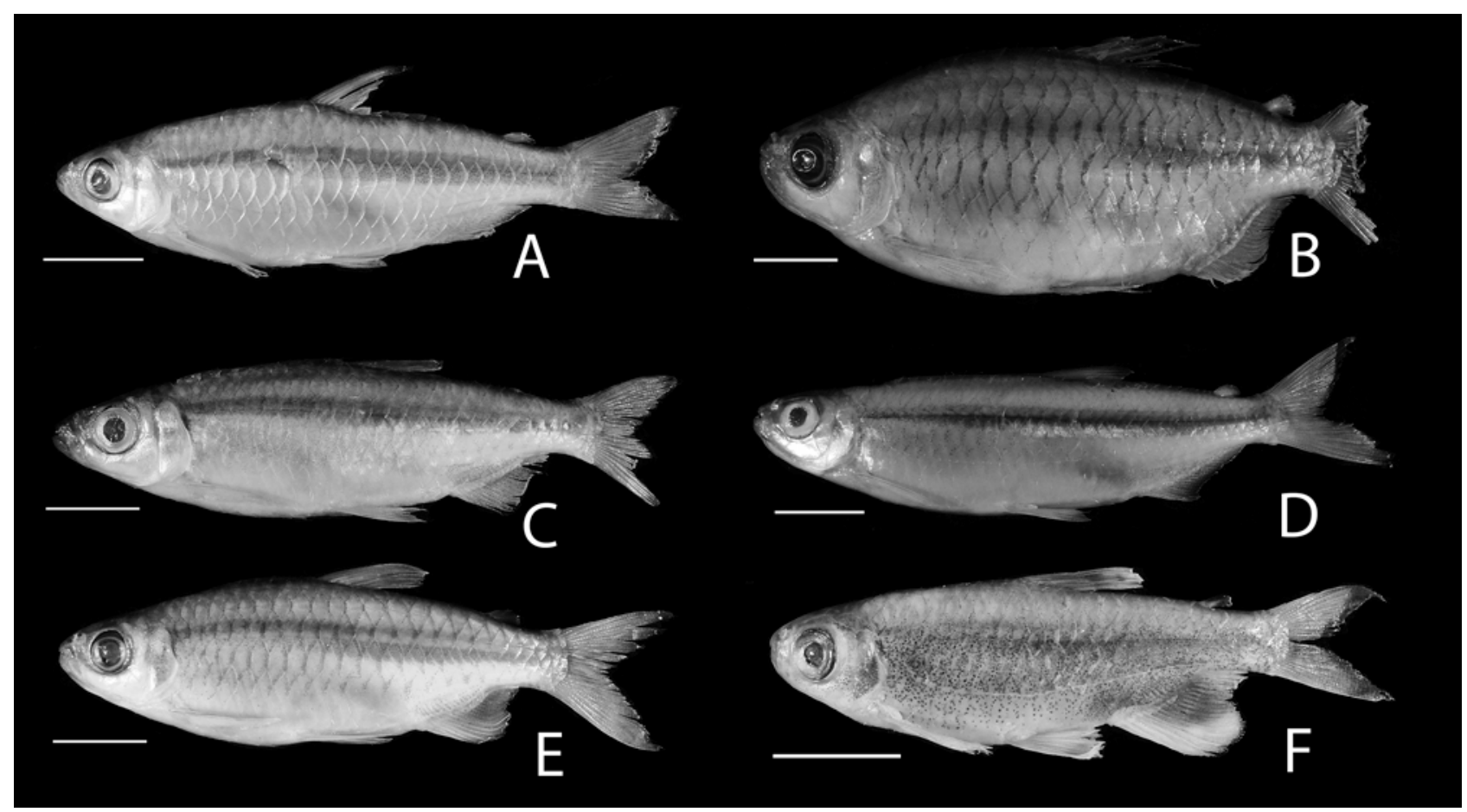

FIGURE 1. Micralestes of the lower Congo River. A) Micralestes acutidens, AMNH 238378, female, $51.1 \mathrm{~mm}$ SL, B) Micralestes holargyreus, AMNH 239479, male, $60.5 \mathrm{~mm}$ SL, C) Micralestes humilis, AMNH 238406, female, $56.8 \mathrm{~mm}$ SL, D) Micralestes lualabae, AMNH 238386, female, $65.4 \mathrm{~mm}$ SL, E) Micralestes stormsi, AMNH 238440, male, 51.0 mm SL, F) Micralestes schelly sp. nov., AMNH 239518, male, $37.7 \mathrm{~mm}$ SL. Scale bars $=1 \mathrm{~cm}$.

\section{Material and methods}

Unless mentioned otherwise, counts and measurements follow Paugy et al. (2003). Visualization of canalbearing scales and teeth was aided by directing a fine jet of compressed air onto the structures. In order to count vertebrae and fin rays, and to visualize other skeletal features, all specimens were x-rayed and some were cleared and stained following a modified protocol based on Taylor \& van Dyke (1985). Vertebral counts include the four modified Weberian centra but exclude the terminal, hypural-bearing vertebra. Gill raker counts correspond to the total number of rakers arrayed along the first arch. Longitudinal and lateral line scale counts terminate at the hypural fold and do not include the few scales on the base of the caudal fin. Throughout this paper the phylogenetic species concept is adopted as a basis for species diagnosis. 
The following comparative materials have been included in this study (values after catalog number indicate number of specimens examined and do not necessarily correspond to the total number of specimens in the lot; C\&S indicates cleared-and-stained preparation and SL indicates standard length. Institutional abbreviations follow Leviton et al. (1985).

Alestopetersius brichardi-AMNH 240416, 5, 2 C\&S; A. hilgendorfi-AMNH 240421, 3, 1 C\&S; Bathyaethiops caudomaculatus-AMNH 238423, 5, 2 C\&S; Brachypetersius altus-AMNH 240420, 5; AMNH 240485, 2 C\&S; B. huloti-AMNH 238374, 2, 1 C\&S; Brycinus macrolepidotus-AMNH 240383, 6, 1 C\&S; B. poptae-AMNH 240385, 5, 1 C\&S; Bryconaethiops microstoma-AMNH 238328, 4, 2 C\&S; B. yseuxi-AMNH 239455, 10, 2 C\&S; Duboisialestes tumbensis-AMNH 238391, 5, 3 C\&S; Hemmigrammopetersius barnardi-AMNH 19861, 10, 3 C\&S; Micralestes acutidens—BMNH 1861.3.10: 3-4, syntype, 1; AMNH 227634, 1; AMNH 239475, 5, 2 C\&S; M. ambiguous-MRAC G.966 a-c, paratypes, 2; M. comoensis -AMNH 097605, 4; M. congicus-MRAC 96582, 1, holotype; AMNH 238430, 5, 1 C\&S; M. eburneensisAMNH 32763, 5, 1 C\&S; M. elongatus-AMNH 215347, 8, 1 C\&S; M. fodori-MRAC 140901, 1, holotype; M. holargyreus-BMNH 1873.7.28: 19, 1, syntype; AMNH 239257, 4 C\&S; AMNH 239479, 10; AMNH 239480, 3; M. humilis-MRAC 805, 1, holotype; AMNH 238406, 1; AMNH 238427, 1; AMNH 240417, 4, 1 C\&S; M. lualabae-MNHN 1967-0668, paratypes, 2; AMNH 5805, 10, 2 C\&S; AMNH 238386, 3; M. occidentalis-AMNH 215533, 1; M. sardina-MRAC 50040, lectotype, 1; MRAC 50041-51, paralectotypes, 3; M. stormsi-BMNH 1902.4.14: 28-31, syntypes, 3; AMNH 239197, 5; AMNH 238440, 5; AMNH 238437, 4 C\&S; Nannopetersius ansorgii-BMNH 1910.11.28: 71-80, paralectotypes, 4; N. lamberti-AMNH 238370, 3, 2 C\&S; Rhabdalestes aeratus-AMNH 235768, paratypes, 10, 1 C\&S; R. maunensis-AMNH 217434, 5, 1 C\&S; R. rhodesiensis-AMNH 50894, 2; R. septentrionalis-AMNH 230605, 10, 5 C\&S; Rhabdalestes sp.-AMNH 227602, 18, 1 C\&S; Virilia pabrensis-AMNH 50858, 6, 1 C\&S.

\section{Generic assignment}

In the following text and accompanying illustrations an asterisk precedes character numbers. Based on outgroup comparison and on the phylogenetic analysis of Zanata and Vari (2005) the use of superscript " 1 " indicates the hypothesized derived state and superscript " 0 " the plesiomorphic state for each figured character.

On the basis of the following six morphological synapomorphies Zanata and Vari (2005: clade 22) diagnosed a large clade of alestids broadly corresponding to the Petersiini of previous authors; an incomplete supraorbital ring (Fig. $2 *^{*} 1^{1}$ vs. Fig. $2 *^{*} 1^{0}$ ), a shelf-like process on the anterolateral margin of the mesethmoid, the major cusp of the symphyseal inner row tooth on the dentary, when present, smaller than the cusps of the outer row symphyseal tooth (Fig. 3. $* 2^{1}$ ), no supraneural associated with the fourth vertebra, postcleithrum 3 , when present, without a lamella, sixth infraorbital without an anterodorsal branch of the laterosensory canal (Fig. $2.3^{1}$ vs. Fig. $2 * 3^{0}$ ). Micralestes schelly exhibit all of these synapomorphies. Within clade 22, Zanata and Vari (2005) further diagnosed two large subclades. Subclade 23, comprised of the genera Micralestes, Hemmigrammopetersius, Rhabdalestes and Virilia is diagnosed on the basis of three characters; the absence of a supraorbital bone (Fig. $2 . * 4^{1}$ vs. Fig. $2 * 4^{0}$ ), the presence of a deep-lying midlateral stripe extending onto the caudal peduncle (Fig. $4 *^{*} 5^{1}$ ), and the presence of a band of dark chromatophores above the anal fin (Fig. 4. $\left.{ }^{*} 6^{1}\right)$. Micralestes schelly exhibit all of these synapomorphies also. The second subclade of Zanata and Vari (2005), their clade 31, contains the remaining petersiin genera and is diagnosed on the basis of 7 characters, only one of which is (polymorphically) present in Micralestes schelly, i.e., outer tooth row of premaxilla with two teeth present. Micralestes schelly shares none of the six other features discussed by Zanata and Vari in their diagnosis of subclade 31 (see e.g., Fig. $2{ }^{*} 7^{0}$; Fig. $2 *^{*} 8^{0}$ ). Based on this character distribution we place M. schelly as members of Zanata and Vari's subclade 23.

Within subclade 23, Zanata and Vari (2005) were able to diagnose a clade formed of the genera Rhabdalestes, Virilia and Hemmigrammopetersius to the exclusion of Micralestes. In addition to the absence of inner row teeth on the dentary (reversed in Virilia), Rhabdalestes, Hemmigrammopetersius and Virilia share a series 
of modifications of the anal fin, none of which are present in Micralestes schelly which, for example, lack all trace of hypertrophy of the third unbranched anal fin ray even in sexually mature males (see e.g., Fig. $4 . * 9^{0}$ ).
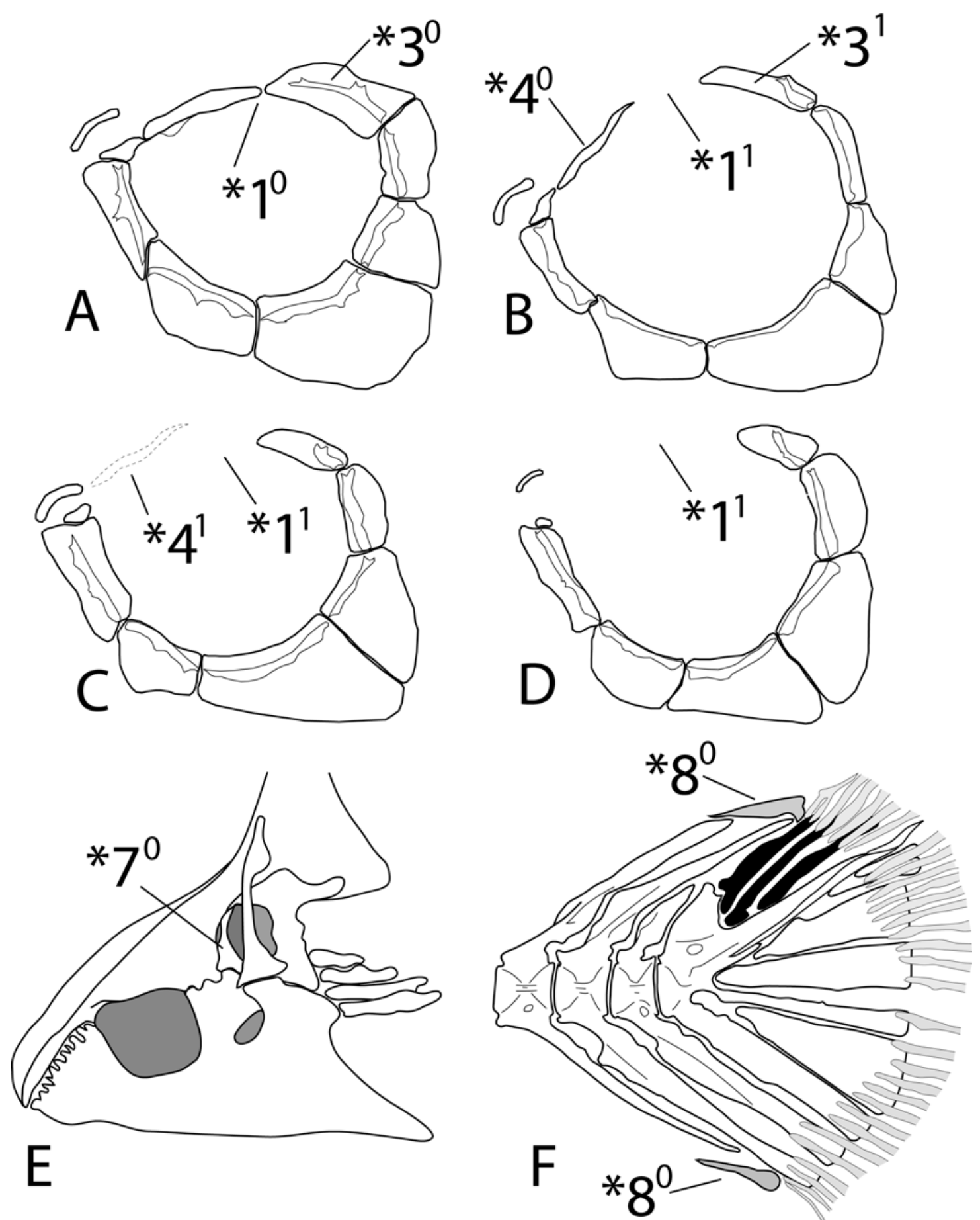

FIGURE 2. Isolated orbital series in A) Bryconaethiops yseuxi, B) Brachypetersius altus, C) Micralestes humilis, D) Micralestes schelly sp. nov., E) pectoral girdle in medial view of Micralestes humilis, F) caudal skeleton and adjacent vertebrae in Micralestes humilis.

Unfortunately neither Zanata and Vari (2005) nor the present study has located any morphological characters supporting the monophyly of the residual Micralestes. The genus thus lacks a rigorous phylogenetic diagnosis and as currently conceived encompasses a wide range of external morphological diversity (see e.g., Fig. 1), and considerable anatomical variability. Ongoing morphological and molecular analyses may reveal the present grouping to be non-monophyletic, nonetheless given the data available, and as an expedient for a cor- 
rect accounting of species diversity in the lower Congo River, it seems reasonable to provisionally assign the new species to this genus.

\section{Micralestes schelly, new species}

(Figs 1F, 2D, 3-6)

Holotype (Fig. 5B) AMNH 240662, male, 40.1 mm SL; Democratic Republic of Congo, Bas Congo Province, Congo River main channel near Inga at point 50 (5 31.69 S 13 36.47 E), R.C. Schelly et al., 26 Sept. 2002.

Paratypes (Fig. 1F, 5B), with same data as holotype. AMNH 239518, $33.9-48.9 \mathrm{~mm}$ SL (24 alcoholic, 5 cleared and stained), MRAC 2007-26-P-1-2, 36.5 - 39.0 mm SL (2 alcoholic), MNHN 2007-1629, 35.3 $40.1 \mathrm{~mm}$ SL (2 alcoholic), ZSM 33982, 39.0 - $44.2 \mathrm{~mm}$ SL (2 alcoholic), MCZ 166773, 34.6 - $36.5 \mathrm{~mm}$ SL (2 alcoholic), CU 93431, 36.9 - 40.0 mm SL (2 alcoholic).

Diagnosis. A member of a clade of small alestid fishes characterized by the combination of the absence of a supraorbital bone, and the presence of a deep-lying midlateral stripe extending along the body onto the caudal peduncle, a band of chromatophores above the anal fin, and a small pair of inner row symphyseal teeth on the dentary. Micralestes schelly is distinguished from all putative congeners in having an elevated vertebral count of $38-40$ (mean 39) versus $34-36$ (mean 35) vertebrae. Additionally the species is characterized by the presence of 4-6 outer row premaxillary teeth with a majority of specimens ( 23 of 40 ) with only four outer row teeth implanted in an alternating pattern with respect to the anterior inner row premaxillary teeth. Mature males are further diagnosed by live coloration, which is dominated by a broad, blue-green iridescent midlateral band extending from behind the opercle to the base of the caudal fin, and by a marked expansion of the band of black chromatophores above the anal fin.

Description. Based on the holotype and 39 paratypes. See Figs. 5 and 6 for general appearance, and Table 1 for summary of morphometric and meristic data. Diminutive species, maximum observed size $48.9 \mathrm{~mm}$ SL. Relatively deep bodied, somewhat laterally compressed with greatest body depth at, or a little in front of, dorsal-fin origin. Dorsal body profile more-or-less smoothly convex to caudal peduncle, less strongly so in mature males; ventral profile markedly convex to anal-fin insertion. Caudal peduncle slightly longer than deep. Mouth terminal, gape not reaching beyond level of anterior margin of eye. Eye moderately large, flanked by adipose membrane extending over snout to level of nostril and posterodorsally over postorbital region. Nostril large and prominent; nasal and antorbital bones greatly reduced in size (Fig. 2D).

Teeth. Stout tri- or quadri-cuspid teeth in outer row on premaxillae variable in number; majority of individual have two teeth on either premaxilla ( 23 of 40 specimens), 13 specimens have two teeth on one side and three teeth contralaterally, and four specimens have three teeth on both premaxillae. When only two teeth are present each is positioned opposite interspaces between and alternating with, anterior inner row teeth (Fig. 3A). Four inner row teeth on each premaxilla, most with one large central cusp and two or three minor cusps on either side, symphyseal teeth often with single minor cusp on medial face. Four outer row teeth on contralateral dentaries, each with large central cusp and two or three minor cusps on either side. A single pair of small, conically recurved, symphyseal inner row teeth on lower jaw invariably present (Fig. 3B).

Fins. Dorsal-fin rays ii, 6-7 (total rays, 8-9), anal-fin rays iii, 16-17 (total rays 19-20). Origin of dorsal fin at, or slightly behind, vertical through pelvic-fin origin. Marked sexual dimorphism in morphology of anal fin (see Figs. 4, 5). However, unlike condition in Rhabdalestes, Hemigrammopetersius and Virilia (Stiassny and Schaefer, 2005; Zanata and Vari, 2005) there is no posterior curvature or hypertrophy of third unbranched anterior ray of mature males (Fig. 4C).

Squamation. Scales in longitudinal series 26-28 (mean 27) to caudal fin flexure, 1-3 smaller scales continuing over caudal fin base, 4.5 transverse scales between lateral line and dorsal-fin origin, 2.5 transverse scale rows between lateral line and pelvic-fin insertion. Lateral line complete, with 25-29 canal-bearing scales to point of hypural flexure, $2-4$ smaller pored scales continuing over caudal-fin base. 
Total number of gill rakers on first gill arch 18-22 (mean 19). Total number of vertebrae 38-40 (mean 39).

Color in alcohol. Base body coloration yellowish brown dorsally and laterally, yellow-orange ventrally. A darkly pigmented, deep-lying midlateral stripe extends from posterior margin of opercle to base of caudal fin. Well-marked band of dark melanophores present above anal fin. Pectoral and pelvic fins pale yellow. Adipose fin tipped in black. Dorsal and caudal fins somewhat dusky. Anal fin of females dusky proximally, in males pigmentation is somewhat expanded distally in posterior portion of fin.

TABLE 1. Morphometric and meristic data for holotype and paratypes of Micralestes, new species.

\begin{tabular}{|c|c|c|c|c|c|}
\hline \multirow[b]{2}{*}{ Morphometrics } & \multirow[t]{2}{*}{ holotype } & \multicolumn{3}{|c|}{ holotype + paratypes } & \multirow[b]{2}{*}{ mean } \\
\hline & & $\min$ & $\max$ & $\mathrm{n}$ & \\
\hline Standard length (mm) & 40.1 & 33.9 & 48.9 & 40 & 38.1 \\
\hline \multicolumn{6}{|l|}{$\%$ head length } \\
\hline Eye diameter & 35.9 & 32.1 & 43.7 & 37 & 37.8 \\
\hline Interorbital width & 38.4 & 27.5 & 45.6 & 37 & 36.2 \\
\hline \multicolumn{6}{|l|}{$\%$ standard length } \\
\hline Head length & 25.8 & 24.7 & 29.1 & 37 & 26.8 \\
\hline Body depth & 30.5 & 26.6 & 33 & 37 & 31.1 \\
\hline Predorsal length & 47.7 & 40.9 & 51 & 37 & 47.3 \\
\hline Prepectoral length & 24.6 & 21.3 & 29.1 & 37 & 24.7 \\
\hline Prepelvic length & 49.2 & 45.7 & 51.8 & 37 & 48.9 \\
\hline Preanal length & 68.1 & 64.6 & 69.3 & 37 & 66.8 \\
\hline Dorsal-adipose & 24.1 & 21.4 & 26.8 & 37 & 23.8 \\
\hline Dorsal-fin base & 12.5 & 9.3 & 15.3 & 37 & 11.5 \\
\hline Anal-fin base & 21.4 & 17.1 & 23.2 & 37 & 19.6 \\
\hline Caudal peduncle length & 12.4 & 11.2 & 17.3 & 37 & 12.8 \\
\hline Caudal peduncle depth & 10.4 & 9.3 & 12 & 37 & 10.9 \\
\hline \multicolumn{6}{|l|}{ continued. } \\
\hline Meristics & & $\min$ & $\max$ & $\mathrm{n}$ & median \\
\hline Total number of vertebrae & 38 & 38 & 40 & 40 & 39 \\
\hline Dorsal fin rays & 9 & 8 & 9 & 40 & 8 \\
\hline Anal fin rays & 19 & 19 & 20 & 40 & 19 \\
\hline Gill rakers & 19 & 18 & 22 & 40 & 19 \\
\hline Lateral line scales & 27 & 25 & 29 & 40 & 28 \\
\hline Longitudinal scales & 28 & 26 & 28 & 40 & 27 \\
\hline Lateral line - dorsal fin scale rows & 4.5 & 4.5 & 4.5 & 40 & 4.5 \\
\hline Lateral line - pelvic fin scale rows & 2.5 & 2.5 & 2.5 & 40 & 2.5 \\
\hline Circumpeduncular scales & 10 & 10 & 10 & 40 & 10 \\
\hline
\end{tabular}

Color in life. Recently two male specimens have been collected from the type locality and live coloration recorded (Fig. 6). In life a broad, blue-green iridescent midlateral band covers the lateral flanks and tail from behind the opercle to the base of the caudal fin. This iridescent band overlies and obscures the deep lying midlateral stripe evident in preserved specimens (Fig. 5). Above and below the midlateral band the body is silvery white. Numerous melanophores are present on the head and opercle, and scattered over the body with a concentration around lateral scale margins. An expanded band of black melanophores reaching to the lateral line 
is present above anal fin. Dorsal fin and pectoral fins are dusky gray; adipose fin is pale gray with a dark distal margin. Caudal fin is dusky gray at its base with a median dark band extending to mid-fork, distally the fin is dusky gray and medially each fin fork is deep crimson red. Anterior and distal margins of the anal fin are white, while the remainder of the fin is jet black. Pelvic fins are white. Iris is silvery white with a small red patch dorsally. Unfortunately no female specimens were collected during a recent site visit and female life coloration remains unknown.
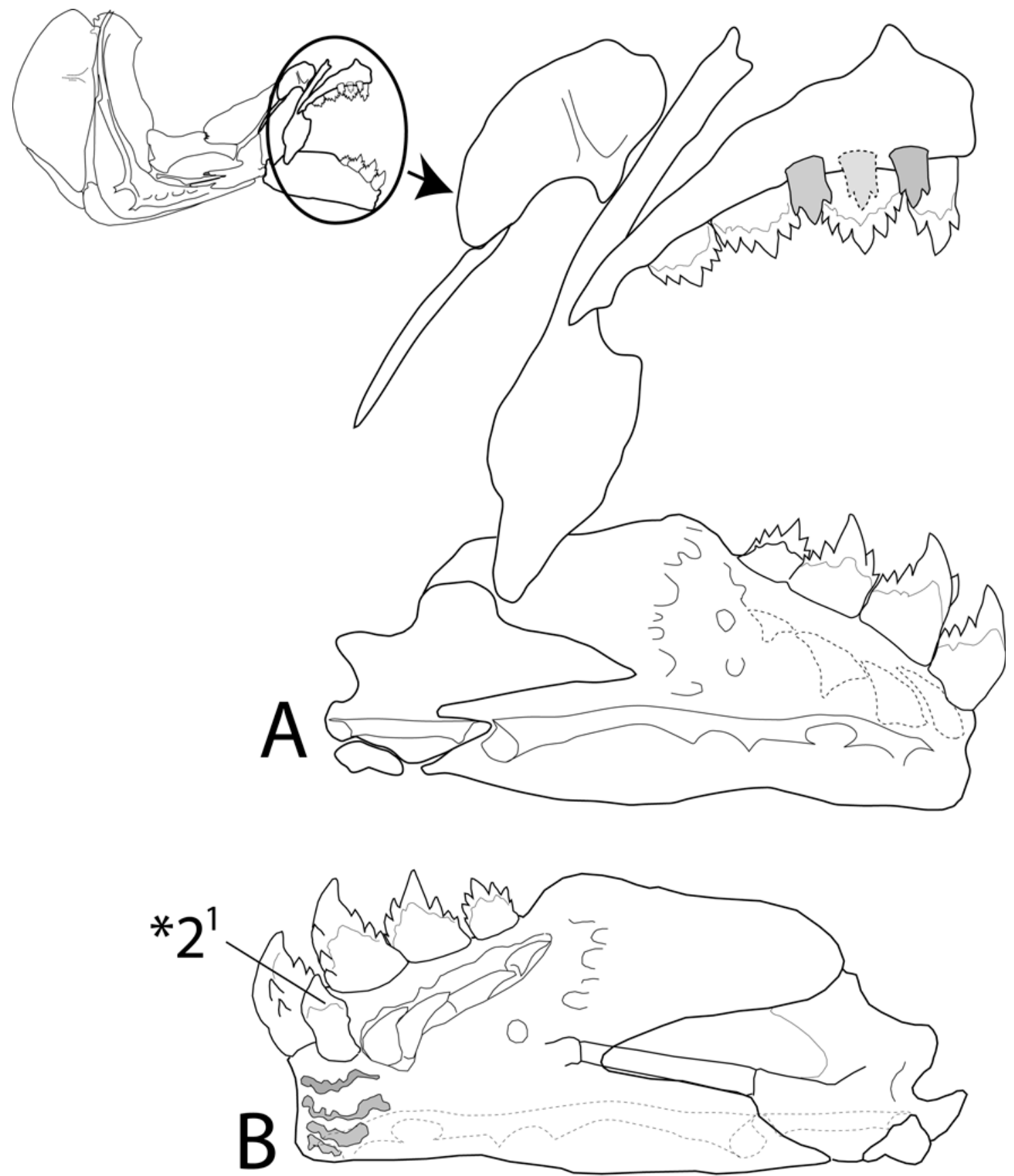

FIGURE 3. Micralestes schelly sp. nov. A) buccal jaws in lateral view, B) dentary in medial view.

Geographical distribution. Known only from the type locality in Bas Congo Province, at Point 50 on the Congo River main channel near Inga, Democratic Republic of Congo ( $\left.5^{\circ} 31.69^{\prime} \mathrm{S} 13^{\circ} 36.47 \mathrm{E}\right)$. Specimens were collected with cast nets in a complex, partially protected riffle habitat adjacent to rapids (Fig. 7). A smallunnamed stream enters the Congo River at this point and supports a patch of forest in the draw between two steep, mostly-bare hills. Micralestes schelly was collected over a sand and gravel substrate in the main chan- 
nel amongst large rock slabs of up to $4 \mathrm{~m}$ high thrusting upward at angles of 60-70 degrees, in pools up to $2 \mathrm{~m}$ in depth. At this site water depth and flow is highly variable due to water surges every 5-10 minutes resulting in depth fluctuations in excess of half a meter.

Etymology. Named for our colleague and the intrepid collector of the type series, Robert C. Schelly.
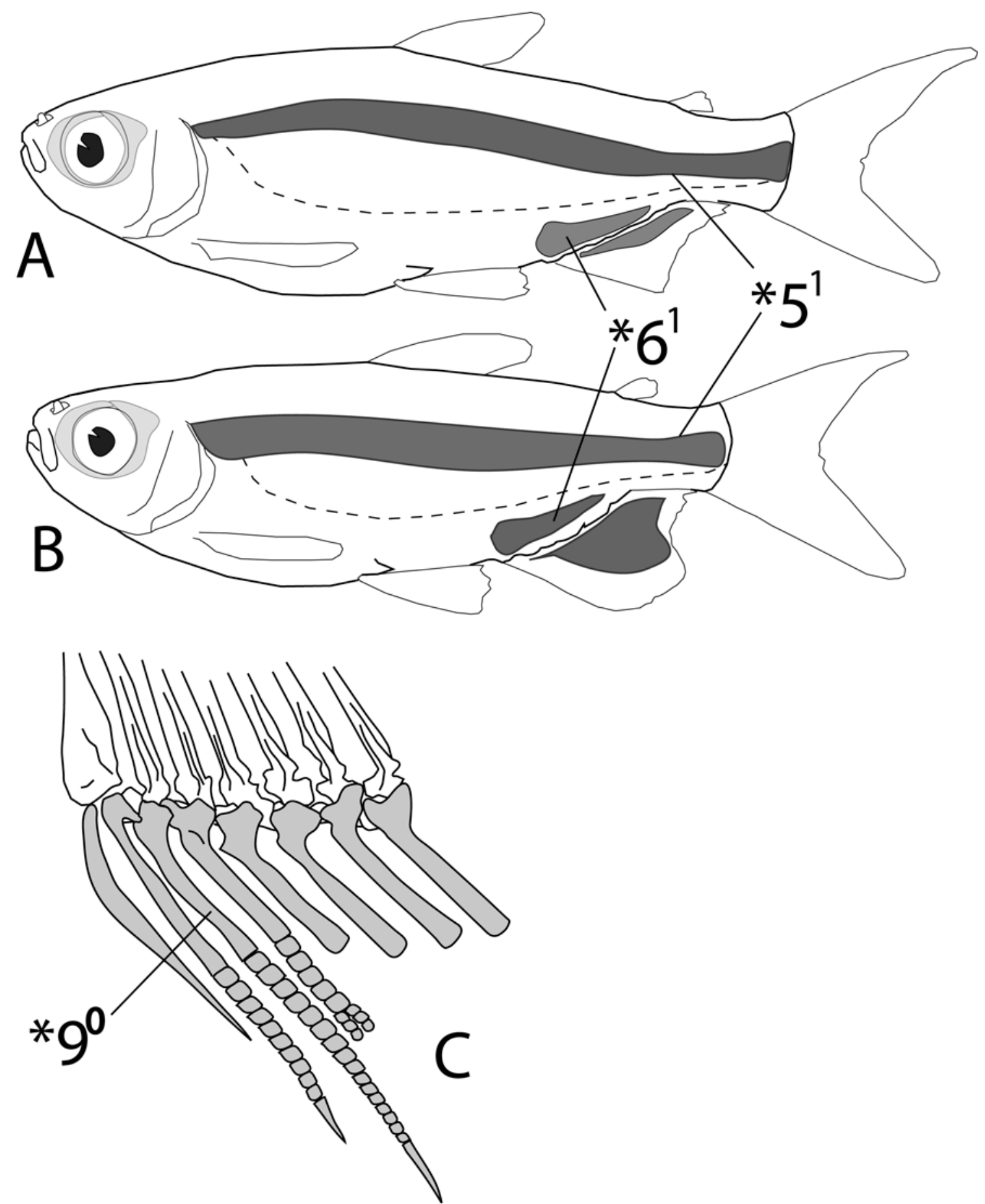

FIGURE 4. Micralestes schelly sp. nov. A) schematic of dominant color pattering in preservation in female, B) male. C) Skeletal elements of anterior region of anal fin of mature male.

Discussion. Recent collections in the region allow us to document the presence of six Micralestes in the stretch of the lower Congo River from Pool Malebo to Boma near the river's mouth, and as an aid for field identification we provide here an illustrated key to those species. 

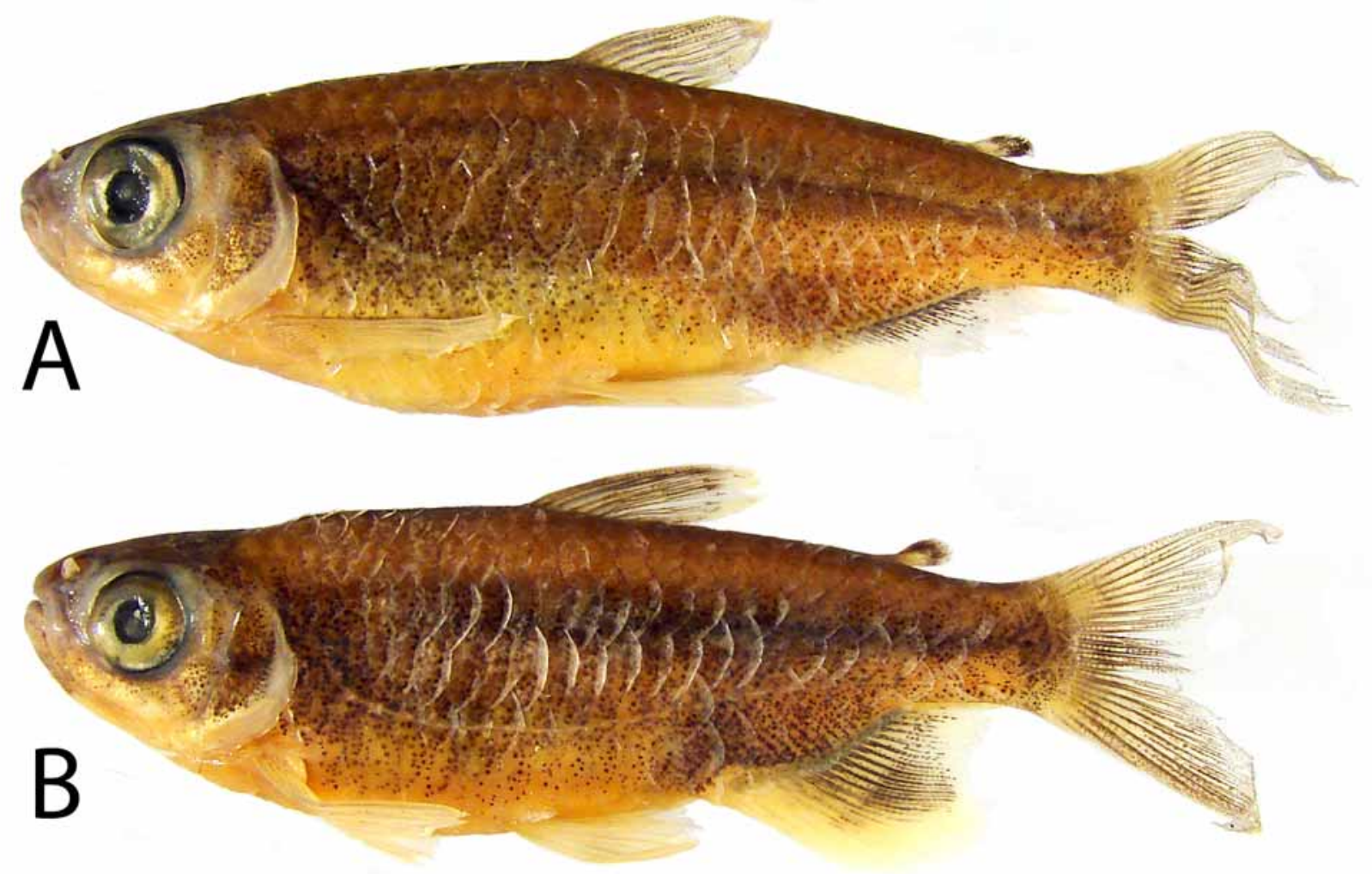

FIGURE 5. Micralestes schelly sp. nov. A) AMNH 239518, paratype, female, $44.5 \mathrm{~mm}$ SL, B) AMNH 240662, holotype, male, $40.1 \mathrm{~mm} \mathrm{SL}$.

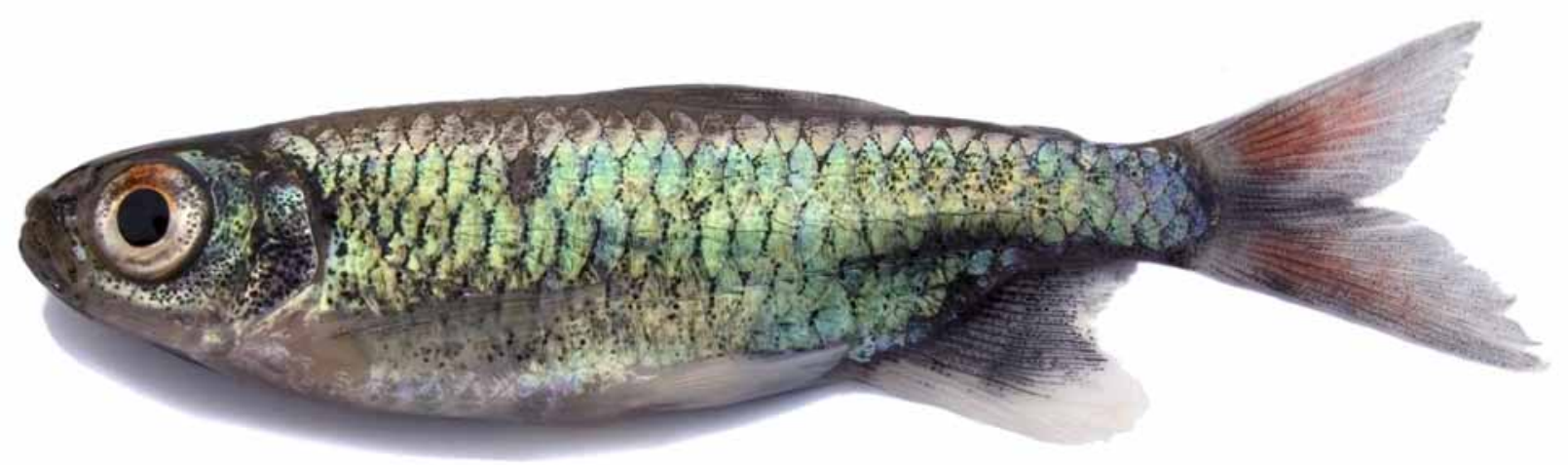

\section{$\mathrm{cm}$}

FIGURE 6. Micralestes schelly sp. nov. AMNH 240671, photograph of mature male taken immediately post mortem. Specimen collected from the type locality in July 2007, photo by Jake Lowenstein.

1A Teeth with numerous small cusps, first inner row premaxillary tooth with 10-12 cusps (Key Fig. 1A). Inner row tooth pair on dentary usually multicuspid (Key Fig. 3A). Dorsal fin with distinctive black apical patch (Key Fig. 2A). M. acutidens

1B Teeth with fewer cusps, first inner row premaxillary tooth with 6-8 cusps (Key Fig. 1B). Inner row tooth pair on dentary invariably unicuspid (Key Fig. 3B). Dorsal fin without black apical patch (Key Fig. 2B).

2A 23-28 scales in longitudinal series from opercle to point of caudal flexure (Key Fig. 2A). 3 


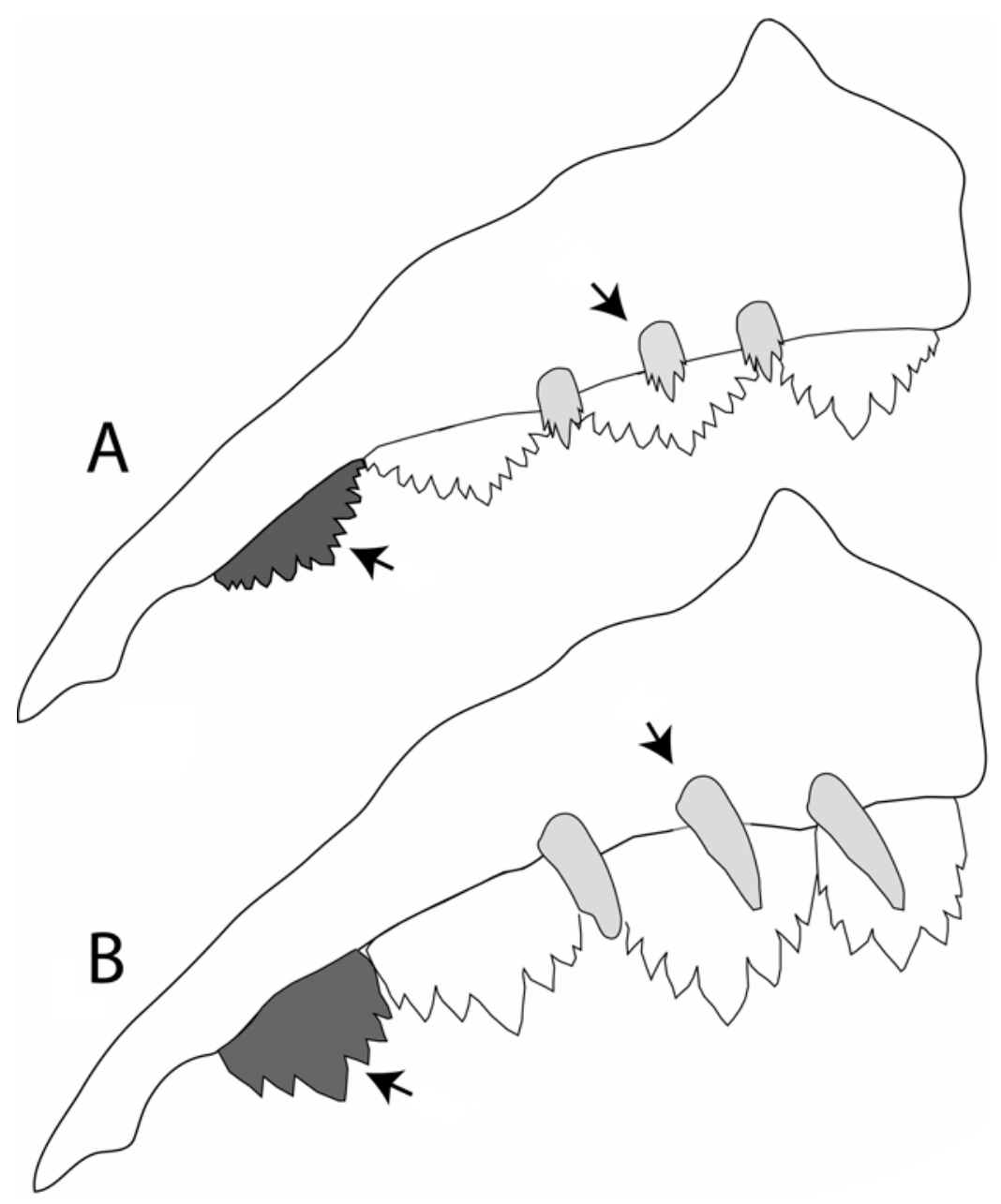

Key figure 1.

2B 29-33 scales in longitudinal series (Key Fig. 2B)

M. lualabae

3A Outer row premaxillary teeth small and tricuspid or quadricuspid (Key Fig. 1A) 4

3B Outer row premaxillary teeth prominent, conical, or weakly shouldered, unicuspids (Key Fig. 1B)

M. holargyreus
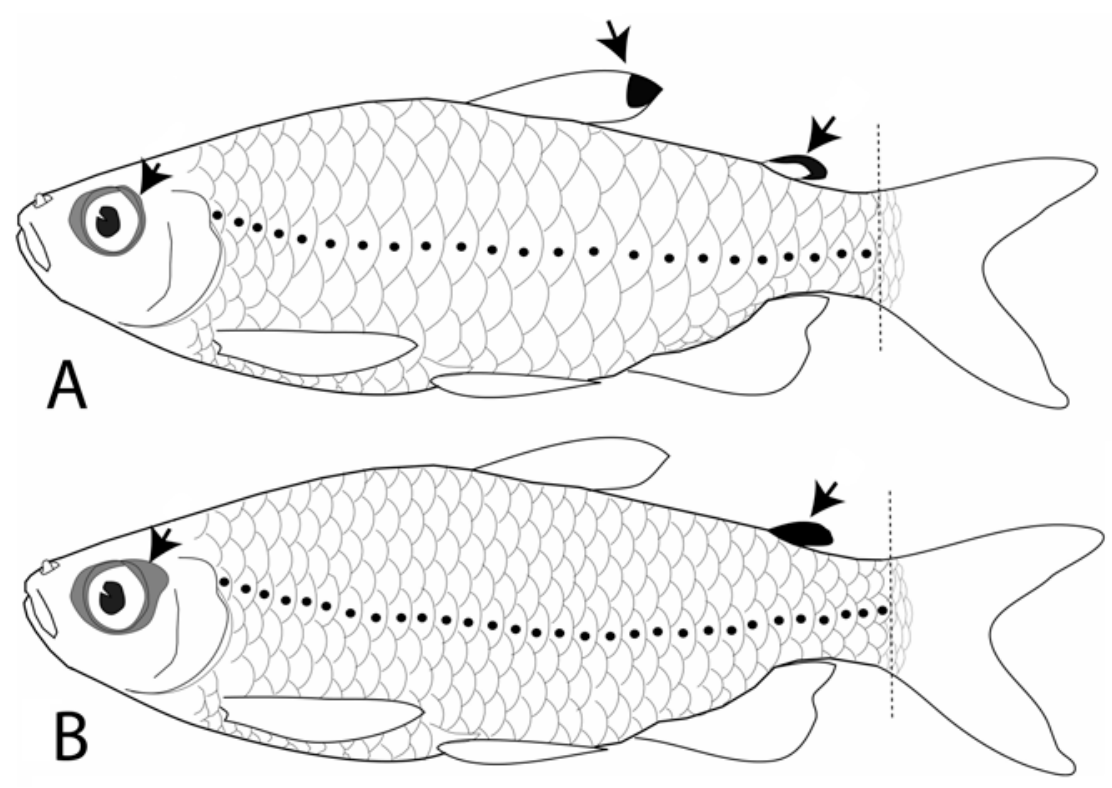

Key figure 2. 
4A Median cusp of symphyseal teeth on dentary less than twice the height of adjacent cusps (Key Fig. 3A). 24-28 scales in longitudinal series from opercle to point of caudal flexure. Adipose fin black distally, pale proximally (Key Fig. 2A)

4B Median cusp of symphyseal teeth on dentary elongate and more than twice the height of adjacent cusps (Key Fig. 3B). 23-24 scales in longitudinal series from opercle to point of caudal flexure. Adipose fin black (Key Fig. 2B)

M. stormsi

5A Relatively gracile, body depth 3.8-4.2 times into standard length. Adipose eyelid restricted posteriorly to orbital margin (Key Fig. 2A)

M. humilis

5B Relatively deep-bodied, body depth 3.0-3.8 times into standard length. Adipose eyelid extending posterodorsally over postorbital region (Key Fig. 2B). M. schelly
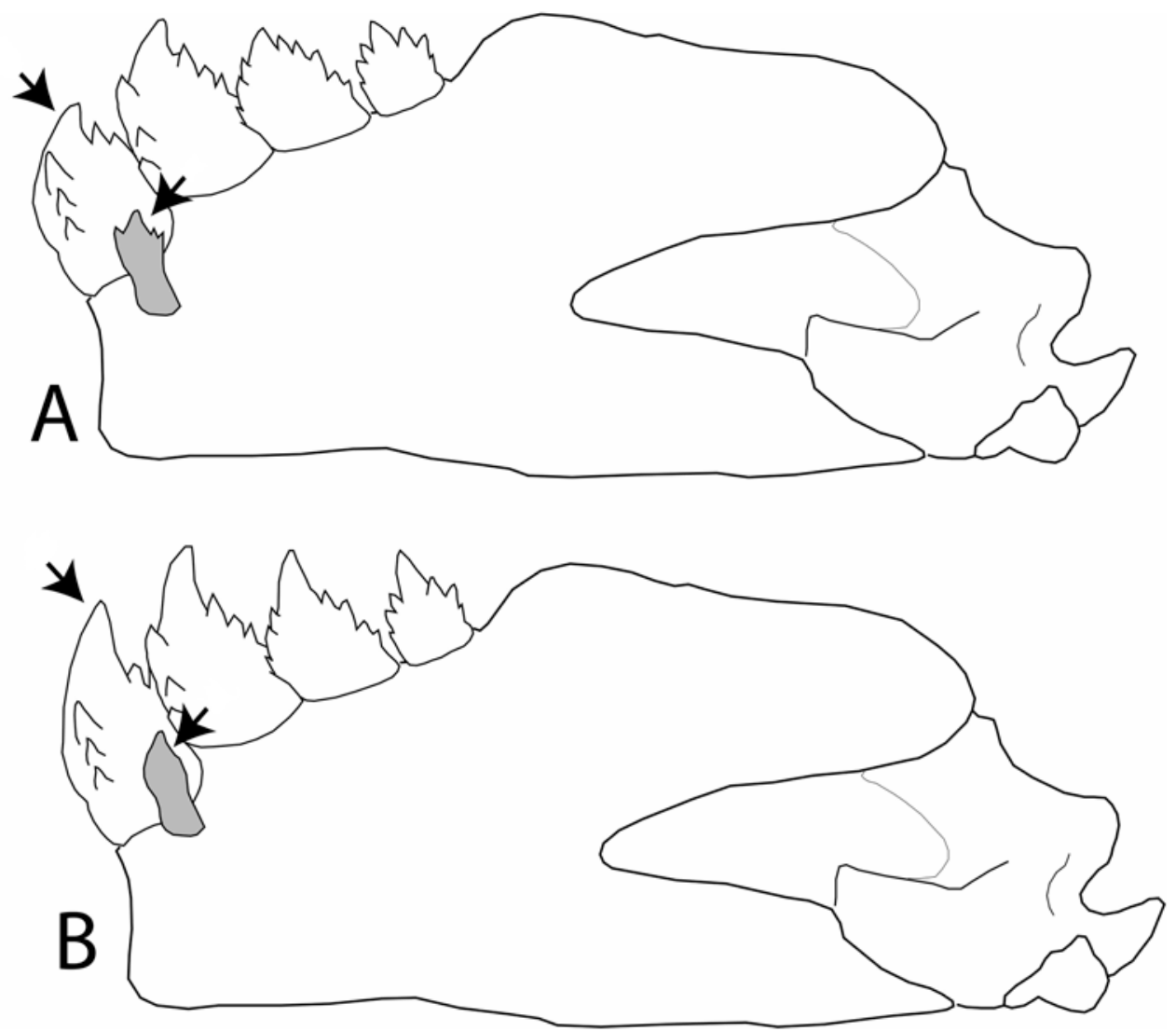

Key figure 3.

Most of these species have widespread distributions encompassing most of the Congo basin and often also much of the rest of Central Africa (Poll, 1967). While we have not undertaken a revision of this genus and related taxa, a task that is ongoing, it is worthy of note that despite intensive collection and surveys in the region Micralestes holargyreus remains known only from the short stretch of the lower Congo River from Boma to Matadi, and M. schelly is only known from a single site in the vicinity of Inga. These two taxa are considered here to be lower Congo River endemics. 


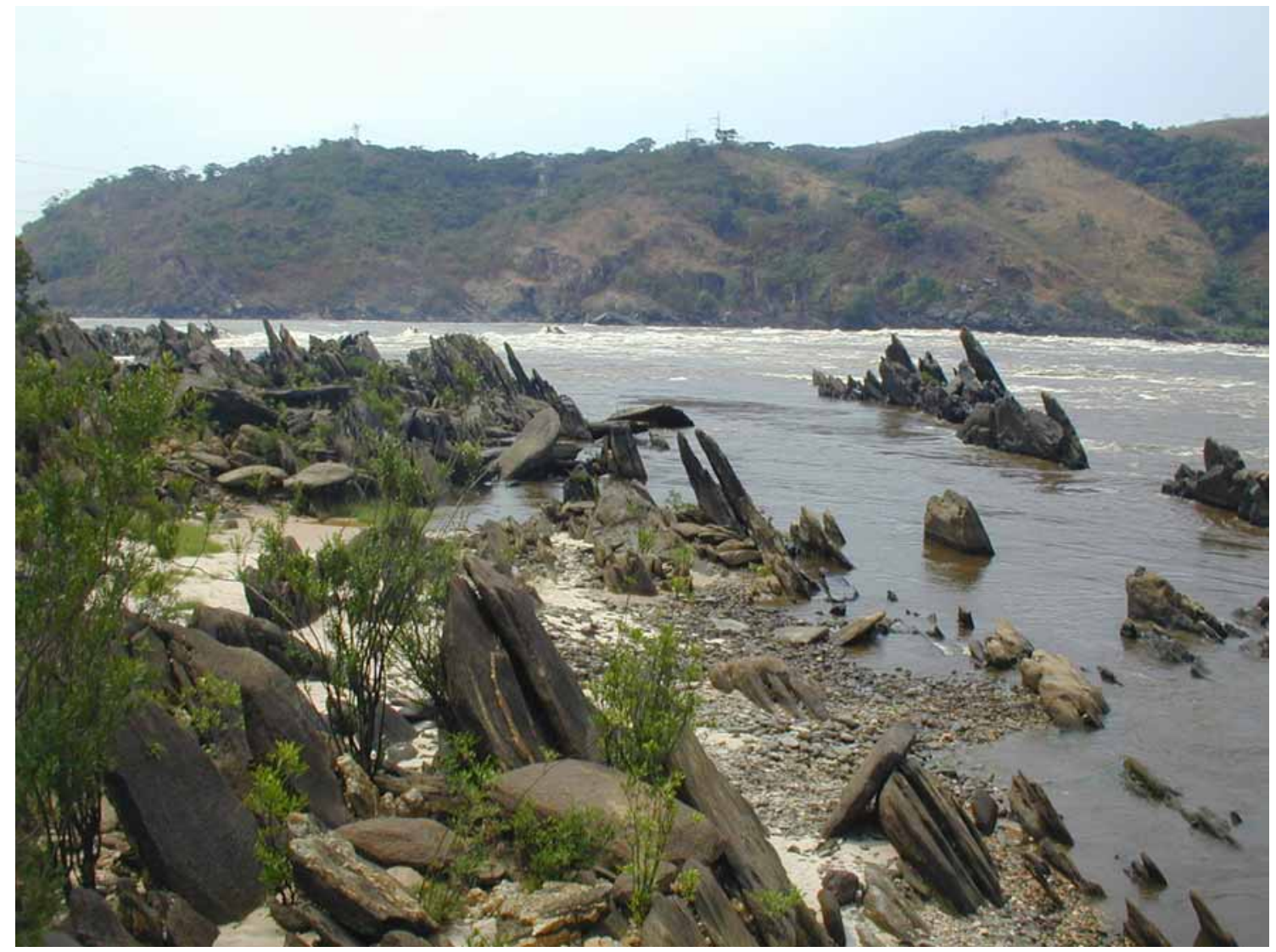

FIGURE 7. Type locality of Micralestes schelly sp. nov., Point 50 on the Congo River main channel near Inga, Bas Congo Province, Democratic Republic of Congo (531.69’S 1336.47E), photo by R.C. Schelly.

\section{Acknowledgements}

Our thanks to J. Maclaine, O. Crimmen, P. Campbell (BMNH), M. Parrent (MRAC) for the loan of materials under their care, and to D. Rodriguez, B. Brown and R. Arrindell (AMNH) for assistance with collection management. For assistance with permits and logistical support we thank the staff and administration of the University of Kinshasa, Democratic Republic of Congo. Research and travel support was provided by National Science Foundation grant number DEB 0542540. Funding for 2002 fieldwork was provided by IRM/USAID with additional support to Robert Schelly provided by the Axelrod Research Curatorship and the Marjorie Merriweather Post Foundation.

\section{References}

Géry, J. (1995) Description of a new or poorly known Alestinae (Teleostei : Characiformes : Alestidae) from Africa, with a note on the generic concept in the Alestinae. Aqua 1(4), 37-64.

Leviton, A. E., Gibbs, R. H., Heal, J. E. \& Dawson, C. E. (1985) Standards in herpetology ad ichthyology: Part 1. Standard symbolic codes for institutional resource collections in herpetology and ichthyology. Copeia, 1985, 802-832.

Paugy, D. (1986) Révision systématique des Alestes et Brycinus africains (Pisces, Characidae). O.R.S.T.O.M. Etudes et Thèses, 1-296.

Paugy, D. \& Schaefer, S.A. (in press). Alestidae. in Stiassny, M.L.J., Teugels, G.G. \& Hopkins, C.D. (eds.) Fresh and Brackish Water Fishes of West Central Africa. IRD, MNHN, MRAC, Collection Faune et Flore Tropicale.

Paugy, D., Lévêque, C. \& Teugels, G. G. (2003) The fresh and brackish water fishes of West Africa. Volume 1. Faune et Flore tropicales 40. IRD, Paris, MNHN, Paris \& MRAC, Tervuren, 1-457. 
Poll, M. (1967) Révision des Characidae nains africains. Annales Musée Royal de l'Afrique Centrale (ser. 8), 162, 1-158.

Roberts, T. R. \& Stewart, D. J. (1976) An ecological and systematic survey of fishes in the rapids of the lower Zaire or Congo River. Bulletin of the Museum of Comparative Zoology, 147, 239-317.

Stiassny, M.L.J. \& Schaefer, S.A. (2005) Rhabdalestes aeratis, new species (Characiformes: Alestidae): first occurrence of the genus from the Middle Congo River basin. Ichthyological Exploration of Freshwaters, 16 (3), 271-278.

Taylor, W. R. \& Van Dyke, G. C. (1985) Revised procedures for staining and clearing small fishes and other vertebrates for bone and cartilage study. Cybium, 9, 107-109.

Zanata, A.M. \& Vari, R.P. (2005) The family Alestidae (Ostariophysi, Characiformes) : a phylogenetic analysis of a trans-Atlantic clade. Zoological Journal of the Linnean Society, 145, 1-144. 
